\title{
Summary of the $\mathrm{NACl}$ systematic review and recommendation on the use of live attenuated influenza vaccine (LAIV) in HIV-infected individuals
}

\author{
Dorothy Moore ${ }^{1,2}$, lan Gemmill ${ }^{3,4}$, Robyn Harrison ${ }^{5,6}$ on behalf of the National Advisory Committee \\ on Immunization (NACl)*
}

\section{Abstract}

Background: Annual influenza vaccination is recommended for all individuals six months of age and older, including those with HIV infection. Prior to this statement, the National Advisory Committee on Immunization (NACl) stated that live attenuated influenza vaccine (LAIV) was contraindicated for all individuals with HIV infection. The objective of this article is to update NACl's guidance on the use of LAIV for HIV-infected individuals.

Methods: A systematic literature review of the use of LAIV in individuals with HIV was undertaken. The Canadian Adverse Events Following Immunization Surveillance System was searched for reports of adverse events following vaccination with LAIV in HIV-infected individuals. $\mathrm{NACl}$ approved the revised recommendations.

Results: $\mathrm{NACl}$ concluded that LAIV is immunogenic in children with HIV, and available data suggest that it is safe, although data were insufficient to detect possible uncommon adverse effects. LAIV may be considered as an option for vaccination of children 2-17 years old who meet the following criteria: 1) receiving highly active antiretroviral therapy for at least four months; 2) CD4 count of $500 / \mu \mathrm{L}$ or greater if age $2-5$ years, or of $200 / \mu \mathrm{L}$ or greater if age 6-17 years; and 3) HIV plasma RNA less than 10,000 copies/mL. LAIV remains contraindicated for adults with HIV because of insufficient data. Intramuscular influenza vaccination is considered the standard for children living with $\mathrm{HIV}$ by $\mathrm{NACl}$ and the Canadian Paediatric \& Perinatal HIV/AIDS Research Group, particularly for those without HIV viral load suppression (i.e. plasma HIV RNA is 40 copies/mL or greater). However, if intramuscular (IM) vaccination is not accepted by the patient or substitute decision-maker, LAIV would be reasonable for children meeting the criteria listed above.

Conclusion: LAIV may be considered as an option for annual vaccination of selected children with HIV.
This work is licensed under a Creative Commons Attribution 4.0 Internationa License.

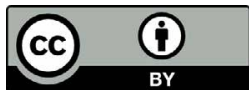

\begin{abstract}
Affiliations
${ }^{1} \mathrm{NACl}$ Influenza Working Group Member

2 McGill University, Montréal, QC ${ }^{3} \mathrm{NACl}$ Influenza Working Group Chair

${ }^{4}$ Queen's University, Kingston, ON

${ }^{5} \mathrm{NACl}$ Influenza Working Group Vice Chair

${ }^{6}$ University of Alberta, Alberta Health Services, Edmonton, AB
\end{abstract}

\section{*Correspondence:}

phac.naci-ccni.aspc@canada.ca
Suggested citation: Moore D, Gemmill I, Harrison R, on behalf of the National Advisory Committee on Immunization (NACl). Summary of the $\mathrm{NACl}$ systematic review and recommendation on the use of live attenuated influenza vaccine (LAIV) in HIV-infected individuals. Can Commun Dis Rep 2020;46(9):299-304.

https://doi.org/10.14745/ccdr.v46i09a08

Keywords: National Advisory Committee on Immunization, NACl, HIV, live attenuated influenza vaccine, literature review

\section{Introduction}

Annual vaccination against influenza is recommended for all individuals with HIV infection (1) who are six months of age or older. Live vaccines are generally contraindicated in persons with immunodeficiency. Nevertheless, criteria have been established to permit vaccination with measles-mumps-rubella and varicella vaccines when immune function is not severely impaired. These 
vaccines have been shown to be safe and are recommended for persons with HIV if the HIV infection is controlled and immune function is satisfactory. The National Advisory Committee on Immunization's (NACl) previous recommendation against live attenuated influenza vaccine (LAIV) use for individuals with immune compromising conditions including HIV was based on expert opinion and the small number of studies available ( $\mathrm{NACl}$ Recommendation Grade D) (2). The product monograph states that LAIV administration to immunosuppressed individuals should be based on careful consideration of potential benefits and risks (3).

Immunization protocols state that LAIV is contraindicated for HIV-infected individuals in British Columbia, Alberta, Manitoba, Saskatchewan and New Brunswick, as well as in the United States (4-10). Some jurisdictions, such as Québec, the United Kingdom, and France (11-13) and professional organizations including the Infectious Diseases Society of America and the British Children's HIV Association $(14,15)$ state that LAIV may be given to individuals with HIV who meet specific criteria.

The objective of this advisory committee statement is to review the evidence for efficacy, effectiveness, immunogenicity and safety for LAIV use in HIV-infected individuals and to provide updated guidance on the use of LAIV in this population.

\section{Methods}

A systematic review of literature on the use of LAIV in HIVinfected individuals was performed. The systematic review's methodology was specified a priori in a written protocol that included review questions, search strategy, inclusion and exclusion criteria and quality assessment. The NACI Influenza Working Group (IWG) reviewed and approved the protocol.

Six electronic databases (EMBASE, MEDLINE, Scopus, ProQuest Public Health, ClinicalTrials.gov and PROSPERO) were searched from inception to April 13, 2018 using search terms for LAIV and HIV. Searches were restricted to articles published in English and French. In addition, hand searching of included studies was performed by checking reference lists to identify additional relevant publications. Hand searching of reference lists was also performed for any relevant retrieved secondary research articles.

Two reviewers independently screened the titles and abstracts and eligible full-text articles.

Studies were included if they met the following criteria:

1. The study population or subpopulation consisted of HIV-infected individuals

2. The study assessed efficacy or effectiveness, immunogenicity, safety (including impact on markers of HIV infection), or vaccine virus shedding
Studies were excluded if they met one or more of the following criteria:

1. The study did not present data on any of: efficacy and effectiveness, immunogenicity, safety or vaccine virus shedding outcomes for LAIV

2. The study was in a language other than English or French

3. The study was a non-human or in vitro study

4. The article was an editorial, opinion, or news report

5. The study presented only secondary research (e.g. literature review, systematic review, meta-analysis)

6. The LAIV investigated was not a seasonal LAIV based on the Ann Arbor backbone

Data were extracted into evidence tables. One reviewer extracted data and appraised the methodological quality of the eligible studies. A second reviewer validated the data extraction and quality assessment. The Canadian Adverse Events Following Immunization Surveillance System (CAEFISS) was also searched for reports of adverse events (AE) following immunization (AEFI) with LAIV in HIV-infected individuals. A narrative synthesis of the extracted data was produced and a recommendation for LAIV use developed. $\mathrm{NACl}$ critically appraised the available evidence and approved the recommendation.

\section{Results}

The systematic review retrieved 220 unique articles, of which eight were retained for data extraction and analysis. These eight articles reported findings from five studies investigating the immunogenicity, safety or both of LAIV in HIV-infected individuals. Four studies were of good quality and one was fair according to ratings of Harris et al. (16). No studies investigating the efficacy or effectiveness of LAIV in this population were identified. A flow diagram of the study selection process is presented in Figure 1. Key study characteristics are summarized in Table 1.

\section{Immunogenicity}

Three studies investigated the immunogenicity of LAIV in a total of 191 HIV-infected children and young adults, 2-25 years of age (18-23), and one study investigated the immunogenicity in 28 HIV-infected adults 18 years of age and older (17). All four studies were of good quality according to the Harris et al. criteria (16). Immunologic correlates of protection against influenza are relatively well established for hemagglutination inhibition $(\mathrm{HI})$ antibodies for adults, but not for microneutralization (MN) antibodies for adults and not for any serological response for children.

There were no major differences in $\mathrm{HI}$ antibody responses following receipt of LAIV between individuals with and without HIV $(17,18,22)$. In the study by Curtis et al. (22), HI response to influenza B/Yamagata was better in the group with HIV than in the HIV-negative control group $(22,23)$. The proportions of 
Figure 1: Flow diagram of the study selection process for the systematic review on the efficacy, effectiveness, immunogenicity and safety of live attenuated influenza vaccine in HIV-infected individuals

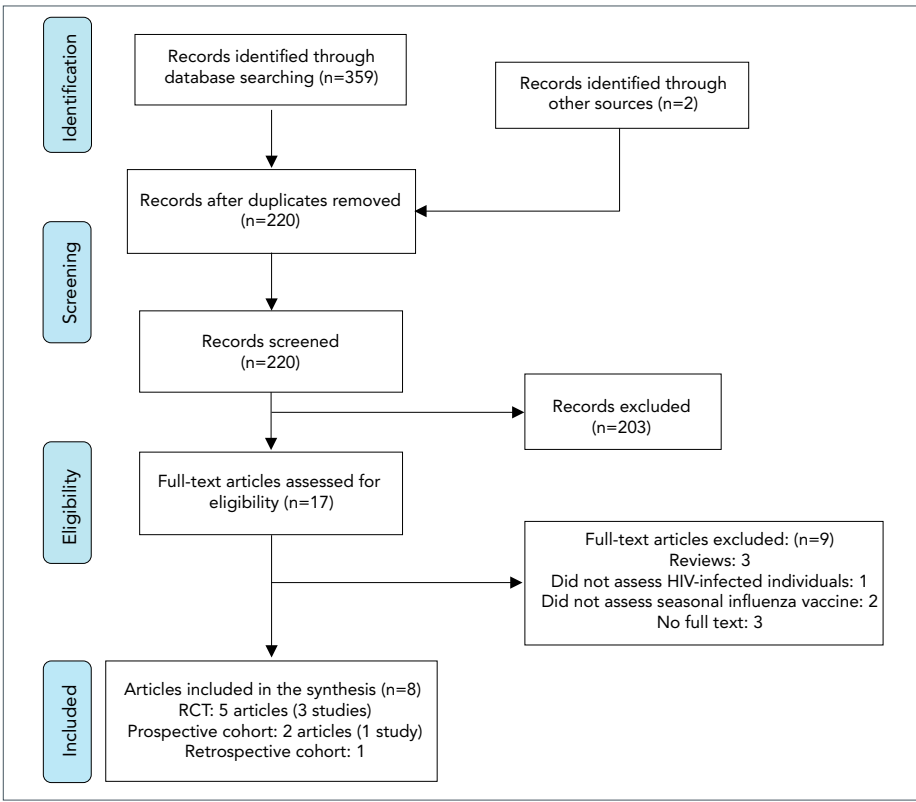

Abbreviation: $\mathrm{RCT}$, randomized controlled trial

$\mathrm{HIV}$-infected individuals with $\mathrm{HI}$ titres of at least 40 vaccinated with LAIV or inactivated influenza vaccine (IIV) were similar for influenza $A(H 1 N 1)$ and $A(H 3 N 2)$ but higher with IIV for influenza $B$ and antibody titres were statistically significantly higher with IIV for influenza $A(H 3 N 2)$ and $B$ vaccine strains (19) and for mismatched strains (20). A significant increase in MN titres was observed against mismatched, but not the vaccine $\mathrm{A}(\mathrm{H} 1 \mathrm{~N} 1)$ strain, in a study of HIV-infected children and young adults $(22,23)$. The proportion of HIV-infected individuals with $\mathrm{MN}$ titres greater than or equal to 1:40 was similar post-vaccination for LAIV and IIV, but the magnitude of response was higher for IIV than LAIV (20).

LAIV induces humoral and mucosal antibody responses as well as $T$ and $B$ cell-mediated responses. Correlates of protection have not been established for LAIV or for cell-mediated responses, and $\mathrm{HI}$ titre may underestimate protection (25). Two studies looked at mucosal antibody responses. There was no important difference in nasal IgA antibody response to LAIV by HIV status $(22,23)$, or in salivary lgG antibody response to LAIV and IIV in HIV-infected individuals $(19,20)$. One study investigated memory B cell and T cell responses. The IgG memory B cell responses did not differ significantly by HIV status for influenza $A(H 1 N 1)$ or $A(H 3 N 2)$; however, a lower absolute response to $\mathrm{B} /$ Yamagata post-vaccination was observed in the HIV-infected group $(22,23)$. The magnitude of the rise in T cell response did not differ by HIV status $(22,23)$.

\section{Safety}

Five studies reported AEFI with LAIV: three in a total of 191 HIV-infected children and young adults $(18,19,22)$, one
Table 1: Characteristics of studies included in the systematic review

\begin{tabular}{|c|c|c|c|}
\hline Author & $\begin{array}{l}\text { Study design } \\
\text { (vaccine } \\
\text { administered) }\end{array}$ & Study population & Outcomes \\
\hline $\begin{array}{l}\text { King et } \\
\text { al., } 2000 \\
(17)\end{array}$ & $\begin{array}{l}\text { RCT } \\
\text { (LAIV3 versus } \\
\text { placebo) }\end{array}$ & $\begin{array}{l}\text { Adults } 18-58 \text { years } \\
\text { of age with HIV } \\
\text { ( } n=57 \text { total; } 28 \\
\text { received LAIV3) and } \\
\text { without HIV ( } n=54 \\
\text { total; } 27 \text { received } \\
\text { LAIV3) } \\
\text { Eligibility criteria for } \\
\text { HIV-infected subject: } \\
\text { Immune class } A 1-2 \text {, } \\
\text { plasma HIV RNA less } \\
\text { than } 10,000 \text { copies/ } \\
\text { mL, and more than } \\
200 \text { CD4 cells/ } / \mathrm{L} \text {; if } \\
\text { less than or equal to } \\
500 \mathrm{CD} 4 \text { cells/ } \mu \mathrm{L} \text {, on } \\
\text { stable antiretroviral } \\
\text { regimen) within three } \\
\text { months prior to } \\
\text { vaccination }\end{array}$ & $\begin{array}{l}\mathrm{HI} \text { antibody } \\
\text { response } \\
\mathrm{AE} \text { within } \\
10 \text { days of } \\
\text { vaccination } \\
\text { Effect on HIV } \\
\text { replication and } \\
\text { CD4 cell counts } \\
\text { Vaccine virus } \\
\text { shedding }\end{array}$ \\
\hline $\begin{array}{l}\text { King et } \\
\text { al., } 2001 \\
(18)\end{array}$ & $\begin{array}{l}\text { RCT } \\
\text { (LAIV3) }\end{array}$ & $\begin{array}{l}\text { Children younger } \\
\text { than } 8 \text { years of age } \\
\text { with HIV }(n=24) ; \\
\text { without HIV ( } n=25) \\
\text { Eligibility criteria for } \\
\text { HIV-infected subject: } \\
\text { Immune class N1-2 } \\
\text { or A1-2 and plasma } \\
\text { HIV RNA less than } \\
10,000 \text { copies/mL } \\
\text { within } 100 \text { days prior } \\
\text { to enrolment }\end{array}$ & $\begin{array}{l}\text { HI antibody } \\
\text { response } \\
\text { AE within } \\
10 \text { days of } \\
\text { vaccination } \\
\text { Effect on HIV } \\
\text { replication and } \\
\text { CD4 cell counts } \\
\text { Vaccine virus } \\
\text { shedding }\end{array}$ \\
\hline $\begin{array}{l}\text { Levin et } \\
\text { al., } 2008 \\
(19) \\
\text { Weinberg } \\
\text { et al., } \\
2010 \mathrm{a} \\
(20) \\
\text { Weinberg } \\
\text { et al., } \\
2010 \mathrm{~b} \\
(21)\end{array}$ & $\begin{array}{l}\text { RCT } \\
\text { (LAIV3 vs. } \\
\text { IIV3) }\end{array}$ & $\begin{array}{l}\text { Children } 5 \text { to less } \\
\text { than } 18 \text { years of age } \\
\text { with HIV ( } \mathrm{n}=243 \\
\text { total; } 122 \text { received } \\
\text { LAIV3; } 121 \text { received } \\
\text { IIV3) } \\
\text { Eligibility criteria } \\
\text { for HIV-infected } \\
\text { subject: Stable HIV } \\
\text { on HAART for more } \\
\text { than or equal to } 16 \\
\text { weeks and with HIV-1 } \\
\text { plasma RNA fewer } \\
\text { than } 60,000 \text { copies/ } \\
\text { mL within } 60 \text { days } \\
\text { prior to vaccination. } \\
\text { All subjects had } \\
\text { received IIV3 in at } \\
\text { least one of the prior } \\
\text { two years }\end{array}$ & $\begin{array}{l}\mathrm{HI}, \mathrm{MN} \text { antibody } \\
\text { response } \\
\text { Salivary mucosal } \\
\text { IgA and IgG } \\
\text { antibody } \\
\text { response } \\
\text { T cell response } \\
\text { AE within } \\
28 \text { days of } \\
\text { vaccination } \\
\text { Effect on HIV } \\
\text { replication and } \\
\text { CD4 cell counts } \\
\text { Vaccine virus } \\
\text { shedding }\end{array}$ \\
\hline $\begin{array}{l}\text { Curtis et } \\
\text { al., } 2015 \\
(22) \\
\text { Weinberg } \\
\text { et al.,' } \\
2016 \text { (23) }\end{array}$ & $\begin{array}{l}\text { Prospective } \\
\text { cohort study } \\
\text { (LAIV4) }\end{array}$ & $\begin{array}{l}\text { Children and young } \\
\text { adults } 2-25 \text { years of } \\
\text { age with HIV }(n=45) \\
\text { and without HIV } \\
(n=55)\end{array}$ & $\begin{array}{l}\mathrm{HI}, \mathrm{MN} \text { antibody } \\
\text { response } \\
\text { Nasal mucosal } \\
\text { IgA response }\end{array}$ \\
\hline
\end{tabular}


Table 1: Characteristics of studies included in the systematic review (continued)

\begin{tabular}{|c|c|c|c|}
\hline Author & $\begin{array}{l}\text { Study design } \\
\text { (vaccine } \\
\text { administered) }\end{array}$ & Study population & Outcomes \\
\hline $\begin{array}{l}\text { Curtis et } \\
\text { al., } 2015 \\
(22) \\
\text { Weinberg } \\
\text { et al., } \\
2016 \text { (23) }\end{array}$ & $\begin{array}{l}\text { Prospective } \\
\text { cohort study } \\
\text { (LAIV4) } \\
\text { (continued) }\end{array}$ & $\begin{array}{l}\text { Eligibility criteria for } \\
\text { HIV-infected subject: } \\
\text { CD4 greater than } \\
15 \% \text { or more than } \\
200 \text { cells/ } \mu \mathrm{L} \text { on cART, } \\
\text { or greater than } 25 \% \\
\text { or more than } 500 \\
\text { cells/ } \mu \mathrm{L} \text { if not on } \\
\text { cART. All subjects } \\
\text { had received } \\
\text { influenza vaccine in } \\
\text { one or more previous } \\
\text { seasons }\end{array}$ & $\begin{array}{l}\text { IgA and IgG } \\
\text { memory B cell } \\
\text { response; T cell } \\
\text { response } \\
\text { AE within } \\
\text { six weeks of } \\
\text { vaccination } \\
\text { Vaccine virus } \\
\text { shedding }\end{array}$ \\
\hline $\begin{array}{l}\text { Menegay } \\
\text { et al., } \\
2017 \text { (24) }\end{array}$ & $\begin{array}{l}\text { Retrospective } \\
\text { cohort study } \\
\text { (LAIV vs. IIV) }\end{array}$ & $\begin{array}{l}\text { Adults_-all active } \\
\text { duty US Air Force } \\
\text { members diagnosed } \\
\text { with HIV }(n=437)\end{array}$ & $\begin{array}{l}\text { Influenza-like } \\
\text { illness within } \\
30 \text { days of } \\
\text { vaccination }\end{array}$ \\
\hline
\end{tabular}

Abbreviations: AE, adverse event; cART, combination antiretroviral therapy; HAART, highly active antiretroviral therapy; $\mathrm{HI}$, hemagglutination inhibition; IgA, immunoglobulin $\mathrm{A}$; IgG, immunoglobulin G; IIV3, trivalent inactivated influenza vaccine; LAIV, live attenuated influenza vaccine; LAIV3, trivalent live attenuated influenza vaccine; LAIV4, quadrivalent live attenuated vaccine; LAIV3, trivalent live attenuated influenza vaccine; LAIV4, quadrivalent live attenuated
influenza vaccine; MN, microneutralization; RCT, randomized controlled trial; RNA, ribonucleic influenza vaccine; MN,
acid; US, United States

in 28 adults (17) and one in 437 adults investigated only for vaccine-associated influenza-like illness (ILI) (24). Four of the studies were of good quality and one was rated as fair.

In both children and adults with HIV, rates of AEFI with LAIV were comparable to rates observed in individuals without HIV receiving LAIV except for more muscle aches and decreased energy in those with HIV $(17,18,22)$. Rates of AEFI in individuals with HIV receiving LAIV or IIV were also similar, with the exception of more frequent but expected nasopharyngeal symptoms (runny nose and nasal congestion) after LAIV (19). Reports of ILI after receiving LAIV were rare (24). No serious or severe AEFls attributable to LAIV were reported in any study. There have been no reports to CAEFISS of AEFI with LAIV in HIV-infected individuals.

Effects of LAIV on HIV infection were assessed in two studies in children $(18,19)$ and one in adults $(17)$. LAIV had no significant effect on HIV RNA viral load or CD4 count.

Four studies reported on the effect of HIV status on LAIV vaccine virus shedding: three in $191 \mathrm{HIV}$-infected children and young adults $(18,19,22)$ and one in 28 HIV-infected adults $(17)$. Vaccine virus shedding did not differ by HIV infection status $(17-19,22)$.

\section{$\mathrm{NACl}$ recommendation for individual level decision-making}

Following thorough review of the evidence, $\mathrm{NACl}$ made the following recommendation:

$\mathrm{NACl}$ recommends that LAIV may be considered as an option for children 2-17 years of age with stable HIV infection on highly active antiretroviral therapy (HAART) and with adequate immune function* (Discretionary NACI recommendation).

- $\mathrm{NACl}$ concludes that there is fair evidence based on immunogenicity data to recommend the use of LAIV vaccine as an option for children 2-17 years of age with stable HIV infection on HAART and with adequate immune function (Grade B Evidence)

- $\mathrm{NACl}$ concludes that, while LAIV appears to have a similar safety profile to IIV, there is insufficient evidence to detect uncommon AE related to the use of LAIV in HIV infected children (Grade Evidence)

*LAIV should be considered only in children with HIV who meet the following criteria:

- Receiving HAART for at least four months

- Have a CD4 count greater than or equal to $500 / \mu \mathrm{L}$ if $2-5$ years of age, or greater than or equal to $200 / \mu \mathrm{L}$ if 6-17 years of age (measured within 100 days before administration of LAIV)

- Have a level of HIV plasma RNA fewer than 10,000 copies/mL (measured within 100 days before administration of LAIV)

While intramuscular (IM) influenza vaccination is considered the standard for children living with HIV by NACl and the Canadian Paediatric and Perinatal HIV/AIDS Research Group, particularly for those without HIV viral load suppression (i.e. IM, plasma HIV RNA more than 40 copies $/ \mathrm{mL}$ ), LAIV would be reasonable for children meeting the criteria outlined above, if vaccination is not accepted by the patient or substitute decision-maker.

The decision to use LAIV in children with stable HIV should be made on a case-by-case basis. The evidence is considered Grade $B$ as there is no direct evidence on the efficacy or effectiveness of LAIV in HIV-infected individuals and the sample size for the evidence base is small.

- There is evidence that LAIV is immunogenic in children 2-17 years of age with stable HIV infection on HAART and with adequate immune function

- LAIV appears to have a similar safety profile to IIV; however, the total number of subjects assessed is insufficient to effectively detect uncommon or rare $\mathrm{AE}$ 
- Children with HIV receive all the routine childhood vaccines and additional parenteral vaccines warranted by their actual or potential immunocompromised state. Offering intranasal LAIV instead of IIV avoids one IM injection annually. A discussion on preference for route of administration should take place prior to vaccination, and may improve acceptance of the seasonal influenza vaccine $(26,27)$

$\mathrm{NACl}$ concluded that the quantity of evidence available on the immunogenicity and safety of LAIV in adults with HIV is insufficient to justify a change in the current recommendation against the use of LAIV in this group. (Grade I Evidence). This recommendation is based on expert opinion.

The detailed findings of the literature review and additional information supporting this recommendation can be found in the $\mathrm{NACl}$ advisory committee statement: Recommendation on the Use of Live Attenuated Influenza Vaccine (LAIV) in HIV-Infected Individuals (28).

\section{Conclusion}

LAIV is immunogenic in children with HIV and appears to have a similar safety profile to IIV, although uncommon or rare $A E$ may not have been detected. NACI recommends that LAIV may be considered as an option for children 2-17 years of age with stable HIV infection HAART and with adequate immune function. Studies with sufficient sample size to detect uncommon or rare $A E$ or to address efficacy or effectiveness of LAIV in children may not be feasible, given the limited numbers of children with HIV in high income countries where LAIV is used.

\section{Authors' statement}

DM - Writing, original draft, review, editing

IG - Review, editing

$\mathrm{RH}-$ Review, editing

The National Advisory Committee on Immunization (NACl) advisory committee statement: Recommendation on the Use of Live Attenuated Influenza Vaccine (LAIV) in HIV-Infected Individuals was prepared by D Moore, N Dayneka, L Zhao, A Sinilaite, K Young and I Gemmill, on behalf of the $\mathrm{NACl}$ Influenza Working Group and was approved by NACl.

\section{Competing interests}

None.

\section{Acknowledgements}

Influenza Working Group members: I Gemmill (Chair), R Harrison (Vice-Chair), C Bancej, L Cochrane, N Dayneka, L Grohskopf, D Kumar, J Langley, P Wolfe-Roberge, J McElhaney, A McGeer, D Moore, S Smith, B Warshawsky and J Xiong
NACI members: C Quach (Chair), S Deeks (Vice-Chair), N Dayneka, P De Wals, V Dubey, R Harrison, K Hildebrand, C Rotstein, M Salvadori, B Sander, N Sicard and S Smith

Liaison representatives: LM Bucci (Canadian Public Health Association), E Castillo (Society of Obstetricians and Gynaecologists of Canada), A Cohn (Centers for Disease Control and Prevention, United States), J Emili (College of Family Physicians of Canada), M Naus (Canadian Immunization Committee), D Moore (Canadian Paediatric Society) and A Pham-Huy (Association of Medical Microbiology and Infectious Disease Canada)

Ex-officio representatives: J Gallivan (Marketed Health Products Directorate, Health Canada [HC]), E Henry (Centre for Immunization and Respiratory Infectious Diseases [CIRID], Public Health Agency of Canada [PHAC]), M Lacroix (Public Health Ethics Consultative Group, PHAC), J Pennock (CIRID, PHAC), R Pless (Biologics and Genetic Therapies Directorate, HC), G Poliquin (National Microbiology Laboratory, PHAC) and T Wong (First Nations and Inuit Health Branch, Indigenous Services Canada)

The National Advisory Committee on Immunization (NACl) acknowledges and appreciates the contribution of A House, M Laplante, S Ismail, M Tunis, and the Canadian Paediatric \& Perinatal HIV/AIDS Research Group to this statement.

\section{Funding}

The work of the National Advisory Committee on Immunization is supported by the Public Health Agency of Canada.

\section{References}

1. National Advisory Committee on Immunization. Canadian Immunization Guide Chapter on Influenza and Statement on Seasonal Influenza Vaccine for 2019-2020. Ottawa (ON): NACl; 2019 (accessed 2020-02-17). https://www.canada.ca/en/public-health/ services/publications/vaccines-immunization/canadian-immunizatio n-guide-statement-seasonal-influenza-vaccine-2019-2020.html

2. National Advisory Committee on Immunization. Recommendations on the use of live, attenuated influenza vaccine (FluMist ${ }^{\circledR}$ ). Supplemental Statement on Seasonal Influenza Vaccine for 20112012. An Advisory Committee Statement (ACS). Can Commun Dis Rep. 2011;37(ACS-7):1-77. DOI

3. AstraZeneca. Product Monograph: FluMist $₫$ Quadrivalent. 2018 (accessed 2020-02-17). https://pdf.hres.ca/dpd_pm/00047438.PDF

4. U.S. Department of Health and Human Services. AIDS Info. Guidelines for the Prevention and Treatment of Opportunistic Infections in HIV-Exposed and HIV-Infected Children (accessed 2020-02-17). https://aidsinfo.nih.gov/guidelines/brief-html/5/ pediatric-opportunistic-infection/0 
5. BC Centre for Disease Control. Human Immunodeficiency Virus (HIV) Infection. BCCDC; 2018 (accessed 2020-02-17). http://www.bccdc. $\mathrm{ca} /$ resource-gallery/Documents/Guidelines\%20and\%20Forms/ Guidelines\%20and\%20Manuals/Epid/CD\%20Manual/Chapter\%20 2\%20-\%20lmms/Part2/HIV.pdf

6. Alberta Health. Immunization of Specific Populations (Immunosuppressed and Chronic Health Conditions). Government of Alberta; 2019 (accessed 2020-02-17). https://open.alberta.ca/ dataset/aip/resource/8a92b77b-351b-4f1e-9d4d-31aaa9effdb3/ download/AIP-Specific-Populations-Immunocompromised.pdf

7. Manitoba Health, Seniors and Active Living. Seasonal Influenza Immunization Program: Live Attenuated Influenza Vaccine (LAIV) (FluMist ${ }^{\circledR}$ Quadrivalent): Questions and Answers for Health Care Providers. Government of Manitoba; 2018 (accessed 2018-11-01). https://www.gov.mb.ca/health/flu/docs/flumist_hcp.pdf

8. Government of New Brunswick. 2013-2014 FluMist $®$, Live Attenuated Influenza Vaccine, Information for Immunization Providers. Government of NB; 2014 (accessed 2020-02-17). https:// www2.gnb.ca/content/dam/gnb/Departments/h-s/pdf/en/CDC/ vaccines/FLUMISTInformationForlmmunizationProviders.pdf

9. Government of Saskatchewan. Saskatchewan Immunization Manual. Chapter 7 - Immunization of Special Populations. Government of SK; 2015 (accessed 2020-02-17). https://www.ehealthsask.ca/ services/manuals/Documents/sim-chapter7.pdf

10. Grohskopf LA, Alyanak E, Broder KR, Walter EB, Fry AM, Jernigan DB. Prevention and Control of Seasonal Influenza with Vaccines: Recommendations of the Advisory Committee on Immunization Practices - United States, 2019-20 Influenza Season. MMWR Recomm Rep 2019;68(3):1-21. DOI PubMed

11. Ministère de la Santé et des Services sociaux. Vaccinologie pratique: Immunodépression. MSSS; 2019 (accessed 2020-02-17). http:// www.msss.gouv.qc.ca/professionnels/vaccination/piq-vaccinologiepratique/immunodepression/

12. Public Health England. Influenza: the Green Book, Chapter 19. Government UK (updated 2019-04-23; accessed 202002-17). https://www.gov.uk/government/publications/ influenza-the-green-book-chapter-19

13. Haut Conseil de la santé publique. Vaccination des personnes immunodéprimées ou aspléniques. Recommandations actualisées. HCSP; 2014 (accessed 2020-02-17). https://www.hcsp.fr/explore.cgi/ avisrapportsdomaine?clefr $=504$

14. Rubin LG, Levin MJ, Ljungman $P$, Davies EG, Avery R, Tomblyn $M$, Bousvaros A, Dhanireddy S, Sung L, Keyserling H, Kang I; Infectious Diseases Society of America. 2013 IDSA clinical practice guideline for vaccination of the immunocompromised host. Clin Infect Dis 2014;58(3):309-18. DOI PubMed

15. Children's HIV Association (CHIVA). Vaccination of HIV infected children (UK schedule, 2018). CHIVA; 2018 (accessed 2020-02-17). https://www.chiva.org.uk/files/8315/4453/4519/Vaccination_of_HIV_ infected_children_2018.pdf

16. Harris RP, Helfand M, Woolf SH, Lohr KN, Mulrow CD, Teutsch SM, Atkins D; Methods Work Group, Third US Preventive Services Task Force. Current methods of the US Preventive Services Task Force: a review of the process. Am J Prev Med 2001;20(3 Suppl):21-35. DOI PubMed
17. King JC Jr, Treanor J, Fast PE, Wolff $M$, Yan $L$, lacuzio $D$, Readmond B, O'Brien D, Mallon K, Highsmith WE, Lambert JS, Belshe RB. Comparison of the safety, vaccine virus shedding, and immunogenicity of influenza virus vaccine, trivalent, types $A$ and $B$, live cold-adapted, administered to human immunodeficiency virus (HIV)-infected and non-HIV-infected adults. J Infect Dis 2000;181(2):725-8. DOI PubMed

18. King JC Jr, Fast PE, Zangwill KM, Weinberg GA, Wolff $M$, Yan L, Newman F, Belshe RB, Kovacs A, Deville JG, Jelonek M; HIV Influenza Study Group. Safety, vaccine virus shedding and immunogenicity of trivalent, cold-adapted, live attenuated influenza vaccine administered to human immunodeficiency virus-infected and noninfected children. Pediatr Infect Dis J 2001;20(12):1124-31. DOI PubMed

19. Levin $M J$, Song $L Y$, Fenton $T$, Nachman $S$, Patterson J, Walker R, Kemble G, Allende M, Hultquist M, Yi T, Nowak B, Weinberg $A$. Shedding of live vaccine virus, comparative safety, and influenza-specific antibody responses after administration of live attenuated and inactivated trivalent influenza vaccines to HIV-infected children. Vaccine 2008;26(33):4210-7. DOI PubMed

20. Weinberg $A$, Song $L Y$, Walker $R$, Allende $M$, Fenton $T$, Patterson-Bartlett J, Nachman S, Kemble G, Yi TT, Defechereux P, Wara D, Read JS, Levin M; IMPAACT P1057 Team. Anti-influenza serum and mucosal antibody responses after administration of live attenuated or inactivated influenza vaccines to HIV-infected children. J Acquir Immune Defic Syndr 2010;55(2):189-96. DOI PubMed

21. Weinberg A, Song LY, Fenton T, Nachman SA, Read JS, Patterson-Bartlett J, Levin MJ. T cell responses of HIV-infected children after administration of inactivated or live attenuated influenza vaccines. AIDS Res Hum Retroviruses 2010;26(1):51-9. DOI PubMed

22. Curtis D, Ning MF, Armon C, Li S, Weinberg A. Safety, immunogenicity and shedding of LAIV4 in HIV-infected and uninfected children. Vaccine 2015;33(38):4790-7. DOI PubMed

23. Weinberg A, Curtis D, Ning MF, Claypool DJ, Jalbert E, Patterson J, Frank DN, Ir D, Armon C. Immune Responses to Circulating and Vaccine Viral Strains in HIV-Infected and Uninfected Children and Youth Who Received the 2013/2014 Quadrivalent Live-Attenuated Influenza Vaccine. Front Immunol 2016;7:142. DOI PubMed

24. Menegay JL, Xu X, Sunil TS, Okulicz JF. Live versus attenuated influenza vaccine uptake and post-vaccination influenza-like illness outcomes in HIV-infected US Air Force members. J Clin Virol. 2017;95:72-5. DOI

25. Mohn KG-I, Smith I, Sjursen H, Cox RJ. Immune responses after live attenuated influenza vaccination. Hum Vaccin Immunother. 2018;14(3):571-8. DOI

26. Marien AG, Hochart A, Lagrée $M$, Diallo $D$, Martinot A, Dubos F. Parental acceptance of an intranasal vaccine: example of influenza vaccine. Arch Pediatr 2019 Feb;26(2):71-4. DOI PubMed

27. Santibanez TA, Kahn KE, Bridges CB. Do parents prefer inactivated or live attenuated influenza vaccine for their children? Vaccine 2018 Nov;36(48):7300-5. DOI PubMed

28. National Advisory Committee on Immunization. Recommendation on the Use of Live Attenuated Influenza Vaccine (LAIV) in HIV-Infected Individuals. Ottawa (ON): NACl; 2020. https:// www.canada.ca/en/public-health/services/immunization/ national-advisory-committee-on-immunization-naci/live-attenuate d-influenza-vaccine-hiv-infected-individuals.html 